\title{
A Revelação no pensamento de Martin Buber
}

\author{
La Révélation dans la pensée de Martin Buber
}

\section{Newton Aquiles von Zuben*}

Pontifícia Universidade Católica de Campinas (PUCSP), Campinas, SP

\section{Resumo}

Este artigo pretende apresentar o conceito de Revelação no pensamento de Martin Buber como ponto axial e fundante da ontologia da relação ao concretizar a "interpresencialidade" no encontro com o Tu Eterno. A Revelação é um dom de Deus, a presença de Deus ao homem sem um conteúdo doutrinal sob forma de legislação revelada. É o fenômeno pelo qual o homem não sai do momento de encontro supremo do mesmo modo que entrou. À interpelação, o homem responde pela fé (emunah). É no "entre-dois" - zwischen - que ocorre o evento da Revelação (Offenbarung) e a fé (Glauben). A noção de "presença", em seu sentido denso, expressa o mistério do encontro entre Deus e o homem. A palavra de Revelação é esta: Eu sou presente como aquele que sou presente (Ehyeh Asher Ehieh) (Êxodo 3:12).

Palavras-chave: Revelação. Presença. Religiosidade. Encontro.

* NAVZ: Doutor em Filosofia, e-mail: nzuben@puc-campinas.edu.br 


\section{Résumé}

On pretend présenter le concept de Révélation dans la pensée de Martin Buber comme l'axe originaire et fondant de l'ontologie de la relation dans la mesure où il réalise "l'inter-personnalité" dans la rencontre avec le Toi Éternel. La Révélation est un don de Dieu, la presence de Dieu à l'homme et non pas un conténu doctrinal sous forme d'une législation révélée. Elle est le phénomène par lequel l'homme ne sort pas du moment de la rencontre suprême de la même manière dans laquelle il est entré. À l'interpélation l'homme répond par la foi (emunah). Dans l' "entre-deux" - zwischen a lieu l'événement de la Révélation (Offenbarung) et de la foi (Glauben). La notion de présence traduit dans son sens plus dense le mystère de la rencontre entre Dieu et l'homme. La parole de la Révélation est celle-ci: Je suis présent comme celui qui suis présent (Ehyeh Asher Ehyeh) (Exode 3:12).

Mots-clés : Révélation. Présence. Religiosité. Rencontre.

\section{Introdução}

Martin Buber destacou-se como um dos eminentes pensadores judeus do século XX. Uma característica de seu pensamento foi congregar de modo peculiar a herança do Judaísmo e da mística hassídica, a herança cultural filosófica clássica e a alemã. Essa simbiose gerou uma obra de múltiplas facetas, como historiador e estudioso das religiões e do misticismo, filosofia, educação, política, sociologia e tradutor e hermeneuta da bíblia. A inter-relação ocorrida entre as duas realidades deu à obra de Buber certo teor de contestação. De um lado, ele descreve o empobrecimento do judaísmo de seu tempo, preocupado mais com regras e leis a serem observadas do que com o verdadeiro progresso espiritual do indivíduo. Um dos seus tradutores e intérpretes renomados, Walter Kaufmann, assim se referiu a Buber: "Sua intenção originária não foi elaborar um sistema buscando a solução de alguns problemas epistemológicos ou éticos, mas se não for audacioso afirmar numa única pergunta: o que a religião dos meus pais significa para mim hoje?" (SCHILPP; FRIEDMAN, 1967, p. 666). 
O hassidismo foi de especial auxílio no projeto de promover a renovação da piedade. Para substituir um judaísmo legalista e racional, ele propõe uma religiosidade interior, na qual o homem pode entrar em contato face-a-face com Deus. E contra o idealismo hegeliano e kantiano, sua tentativa foi repensar as relações entre os homens e a natureza dos homens, entre si, e do homem com Deus. A via proposta não toma por base um sistema doutrinal dogmático, mas se propõe como impulso a vivência existencial do indivíduo concreto. E sua mensagem está fundada na relação dialógica inter-humana, a qual conduzirá ao encontro com Deus como Tu eterno e pessoa absoluta.

Buber, avaliando-se em face de sua diversificada obra, declarou-se um homem atípico (atypischer Mensch). E, por isso, seu pensamento filosófico não se assemelha à forma tradicional de filosofia sistemática. Conhecemos na história da filosofia diversos autores judeus e suas obras, no campo da filosofia. Ele não segue a linha da tradição que vincula o judaísmo a uma perspectiva filosófica independente deste, como por exemplo, o platonismo de Filão de Alexandria, ou o aristotelismo de Maimônides. O pensamento filosófico de Buber está, ao contrário, sedimentado mais nas fontes judaicas do que nas dos filósofos medievais citados. É pertinente pensar a existência de uma dialética, na qual cada etapa no pensamento filosófico do nosso autor é refletida em sua filosofia do judaísmo. Tais reflexões manifestam mais um judaísmo bíblico e hassídico do que o judaísmo talmúdico dos medievais ou o judaísmo liberal moderno. Dentre seus estudos sobre o judaísmo, manifestou interesse no estudo do misticismo comparado ${ }^{1}$. Mesmo não sendo o foco de seu interesse acadêmico ou de pesquisa, ele ministrou, durante quatro anos, na Universidade de Frankfurt, História comparada das religiões, cuja temática dizia respeito às relações entre a mística do hinduísmo, do taoísmo, do budismo e do hassidismo. Destes, o foco mais direto foi o taoísmo, o hassidismo e o zen-budismo.

A intenção de Buber, por conseguinte, foi a religião. Aliás, na obra Eu e Tu (Ich und Du, de 1923) sua intenção foi resolver a cisão entre religião e a

1 Uma das obras dedicadas ao hassidismo está publicada no Brasil pela editora Perspectiva: Histórias do Rabi. 1. ed. São Paulo, 1995 (Erzählungen der Chassidim, de 1967). 
vida quotidiana ${ }^{2}$. Deus é encontrado no mundo cotidiano. Anteriormente à publicação de Eu e Tu, Buber proferiu uma série de oito conferências, entre 15 de janeiro e 12 de março de 1922, em Frankfurt, no Freies Jüdische Lehrhaus, com o título Religion als Gegwewart, (Religião como Presença). O projeto apresenta uma fenomenologia da religião cujo texto auxiliou na elaboração final da obra citada. Essas conferências serviram para Buber como o caminho para pensar a religião, no cenário da vida dialogal - a religião definida como presença, o "estar-diante-de" (Gergenüberstehen) no encontro com o Tu Absoluto.

O tratamento da religião como presença nas conferências, assim como o interesse inicial de Buber no misticismo, representa uma tentativa de superar as estreitas interpretações racionais e funcionais da religião que prevaleciam no século XIX e início do século XX. Em Religião como presença, no entanto, Buber abandona sua defesa anterior da "experiência de Deus" denunciando a busca de momentos místicos psicológicos ou extáticos (HORWITZ, 1978, p. 30).

Minha intenção neste texto limita-se ao estudo de uma noção bíblica que ocupa um lugar eminente, no pensamento de Buber, vale dizer, a noção de Revelação, apresentada na obra Ich und Du, publicada em 1923 representa interesse por causa de sua interpretação singular da noção de Revelação, se comparada com as concepções tradicionais da teologia judaica e da teologia cristã, católica ou reformada.

Qual o significado desse evento originário (Urphänomen), que traduz uma das experiências religiosas mais intensas do homem, chave para a compreensão da relação entre o humano e o Tu Eterno, o Tu Absoluto? Proponho seguir a seguinte via: expor de modo sucinto aquilo que poderia ser a ontologia da palavra, desenvolvida por Buber, com a correlação de duas "palavras-princípio" (Grundwort), em cuja articulação se constrói o existir humano. O que representa, no pensamento de Buber, essa dupla de conceitos e o modo de instituição do ser humano como ser-de-relação?

2 Riwka Horwitz, filósofa israelense, autora de um livro notável sobre a obra Eu e Tu, afirma: “Eu e Tu é considerado uma das mais influentes obras na filosofia e na teologia contemporâneas. Muitos livros, artigos e comentários foram publicados sobre essa obra prima que Martin Buber, até seus últimos anos de vida, considerou como seu mais importante livro e ponto de partida de seu pensamento dialógico" (HORWITZ, 2007, p. 17).

Rev. Pistis Prax., Teol. Pastor., Curitiba, v. 9, n. 3, 785-809, set./dez. 2017 
Quais as características dos dois mundos a que se refere Buber e como se explica a alternância das atitudes por ele designadas de Eu - Isso e Eu-Tu, e como se dá o diálogo "entre" (Zwischen) o homem e o seu confrontante (Gegenstand ou Gegenüber)? Em seguida, analisar o significado do conhecimento, nas duas atitudes Eu-Isso e Eu-Tu, e apresentar suas intuições a respeito da Revelação (Offenbarung), no encontro entre o homem e aquele que é Presença (eyheh).

\section{A Revelação e a ontologia da relação}

Desde o início de sua trajetória intelectual, no início do século XX, até sua maturidade filosófica, em 1922, pode-se entender que o desenvolvimento do pensamento de Buber parte de uma etapa inicial, dedicada ao misticismo, com estudos sobre a mística cristã e judaica, e seus relevantes estudos sobre o hassidismo - de 1900 a 1912; em seguida, a etapa que poderia ser denominada existencialista, representada, sobretudo, pela obra Daniel (1916); e outra etapa consagrada ao estudo da religião, com as conferências Religion als Gegenwart (Religião como Presença), culminando com Ich und Du, onde expõe sua filosofia do diálogo. Eu e Tu pode ser considerado a charneira de toda a sua construção intelectual. Podemos ter, assim, o antes e o depois de Eu e Tu. A seguir, vem o restante de sua obra, com sua célebre tradução da bíblia hebraica, seus textos de hermenêutica bíblica, estudos no campo da sociologia, da política, da educação, da antropologia filosófica e sobre o judaísmo. Eu e Tu retém muitos elementos de seus estudos sobre a mística cristã, com Jacob Böhme, a mística judaica, em especial o hassidismo, e do período existencialista. Seus interesses nas religiões do oriente, o budismo e o hinduísmo, prevaleceram no período inicial, enquanto o hassidismo e o taoísmo perduraram no período de maturidade filosófica. "Buber mudou a ênfase de seu interesse anterior no Divino Incondicionado panteísta das religiões orientais, para o Deus bíblico da sarça ardente, o ehyeh asher ehyeh que ele denomina o Tu Absoluto" (HORWITZ, 1978, p. 31).

Uma observação deve ser enfatizada: a preeminência da presença da mística hassídica exaustivamente estudada por Buber exerceu forte influência, como fonte seminal, sobre a gênese e a consolidação do pensamento do 
nosso autor. Na verdade, sua intenção foi entender esse fenômeno como um padrão de vida completo, uma busca de vida do homem com Deus no mundo. Buber começa a explorar o mundo da mística com seus estudos sobre o hassidismo, o qual, aos seus olhos, parece uma celebração da vida por meio da realização da alegria dos mandamentos, distante do ascetismo e do rigor do judaísmo rabínico clássico. Tanto em sua experiência vivida (na infância, no seio de comunidades hassídicas) quanto no plano intelectual, ele se sentia profundamente próximo desse hassidismo ${ }^{3}$.

A Revelação, para Buber, está vinculada ao entendimento bíblico da palavra como dinâmica "entre" (Zwischen) Deus e o homem: o ouvir e o responder ao apelo, o "endereçamento da palavra" a toda a criatura. De acordo com Buber, a bíblia hebraica não é mera literatura devocionista ou uma teologia simbólica que nos ensina sobre a natureza de Deus, como Ele é em si mesmo. Revelação é mais do que informações sobre sua essência ou atributos, o encontro entre o homem e a presença Deus. E com efeito, Buber não pode aceitar que afirmações acabadas sobre Deus tenham baixado do céu sobre a terra. A Revelação é presença e nunca passado. Não se reduz a textos escritos, mas é uma Voz falada, proferida, endereçada ao homem no momento presente, para uma situação presente, em sua concretude. "A relação com o ser humano é a verdadeira imagem da relação com Deus, na qual a verdadeira invocação participa da verdadeira resposta. Só que na resposta de Deus tudo, o Todo se revela como uma linguagem (Sprache) (BUBER, 2012, p. 118).

A bíblia é o relato histórico da relação de Deus com o homem, na perspectiva do olhar humano. Em uma de suas obras sobre o judaísmo, Buber afirma:

Nenhum desses livros (Buber refere-se aos livros sagrados de outras as religiões - NT) é, como esse (a bíblia), repleto de dialogo entre o céu e a terra. É nos relatado como, sem cessar, se endereça ao homem, e como o homem se endereça a Deus [...]. A doutrina fundamental que preenche

3 Para informação mais ampla, tomo a liberdade de remeter o leitor a textos de minha autoria: Martin Buber. Cumplicidade e diálogo (2003, p. 59-113); A questão do inter-humano: uma releitura de Eu e Tu de Martin Buber, 2008; Tu Eterno e religiosidade no pensamento de Martin Buber, 2015. 
as páginas da Bíblia hebraica é que nossa vida é um diálogo entre o lá em cima e o aqui embaixo (BUBER, 1982, p. 238-239).

E continua sua argumentação enfatizando que a Bíblia nos ensina

[c] omo, sem cessar, Deus se dirige ao homem e como o homem se dirige a Ele. Deus informa ao homem sobre seu projeto concernente ao mundo [...] Ele lhe descobre suas intenções, chama-o para participar de sua realização. [...]. A Bíblia deu, sob a forma da lembrança transfigurada, a expressão imaginada e decisiva de um eterno evento que se reproduz sem cessar. $\mathrm{Na}$ linguagem dos acontecimentos e das situações. Em sinais continuamente cambiantes que, no entanto, permanecem claros para o observador realmente atento, a transcendência fala ao nosso coração nos momentos essenciais de nossa vida pessoal. E existe uma linguagem nós podemos responder, é aquele de nossos comportamentos e de nossas atitudes, de nossas reações e de nossas abstenções (BUBER, 1982, p. 238).

Pode-se entender, assim, que o ponto axial da fé dos judeus se sustenta na crença segundo a qual Deus, sendo transcendente ao mundo, entra em contato com o mundo e com o homem. Essa crença perdurou até a época moderna, a qual desferiu severas críticas contra a ideia de Revelação. Os ataques não estavam direcionados a uma concepção particular de Revelação de uma determinada religião. O alvo era nitidamente direcionado para a própria possibilidade de Revelação. Essa crítica radical justificava-se pelo fato de ela estar frontalmente contra o princípio de uma investigação racional, defendido pela modernidade. Não se poderiam justificar racionalmente eventos que não pudessem ser explicados por meio de leis naturais ou por causas.

Buber expõe sua concepção de Revelação, na terceira parte de Eu e Tu. Ali se lê: "O que é o eterno: o fenômeno primordial (Urphänomen) presente aqui e agora que nós denominamos a Revelação?" (BUBER, 2012, p. 121). Suas reflexões sobre o Tu eterno, na terceira parte da obra, são intimamente articuladas com as intuições desenvolvidas na primeira parte, onde trata das "palavras-princípio" (Grundwörter). Vê-se aí uma verdadeira ontologia da relação, com a palavra servindo de esteio para o existir humano, na alternância das atitudes manifestas nas "palavras - princípio" Eu-Tu e Eu-Isso, formando respectivamente o mundo da relação, do 
diálogo — Eu-Tu —, e o mundo da experiência e da utilização Eu-Isso — mundo do Isso.

A intuição originária de Buber, em $E u$ e Tu, está na ligação ontológica entre o ser e a linguagem, o dizer, a palavra, Davar. A linguagem está no fundamento do ser do homem como relação. As palavras-princípio estabelecem o homem no ser. "Ser Eu, ou proferir a palavra Eu são uma só e mesma coisa. Proferir Eu ou proferir uma das palavras-princípio são uma e mesma coisa" (BUBER, 2012, p. 52). O homem em diálogo é o lugar privilegiado onde o ser se manifesta em sua dualidade, seja como Tu, seja como Isso. No início de sua obra, postula a diferença fundamental entre as duas palavras-princípio: a linguagem que fala "Eu-Tu" e a linguagem que fala "Eu-Isso". A palavra-princípio Eu-Tu é, por essência, uma invocação, um dizer, um endereçar a palavra (das Anschprechen). Por outro lado, a linguagem da palavra-princípio Eu-Isso é um "falar sobre" (das Besprechen). O mundo do Tu estabelecido pela palavra-princípio Eu-Tu é o mundo da relação (Beziehung), no qual o Tu é uma pessoa. O mundo do Isso, por outro lado, quando o Eu profere a palavra-princípio Eu-Isso, é o mundo da experiência (Erfahrung) e da utilização (Gebrauch) do outro reduzido a uma coisa ou objeto (Gegenstand). "As palavras-princípio não exprimem algo que pudesse existir fora delas, mas uma vez proferidas elas fundamentam uma existência. As palavras-princípio são proferidas pelo ser" (BUBER, 2012, p. 51).

É significativo notar que um dos traços originais de Buber é sua ênfase em sustentar que o encontro imediato, na atitude Eu-Tu, só existe de modo autêntico com a abolição da imagem. Esta representa um obstáculo à verdadeira relação, é uma ilusão. A imediatez implica a recusa dos véus da mediação e da representação. A relação é uma atitude de "palavra" recíproca - a invocação e a resposta - um transcender do esplendor da imagem. A inspiração judaica defende a exclusão de qualquer imagem. Conforme Buber, a imagem é obstáculo para a relação, ela bloqueia qualquer relação Eu-Tu. Relação para Buber é "palavra". Ele segue aqui a concepção rabínica segundo a qual o homem é um "ser falante" (médaber). O judaísmo é "anicônico".

A palavra Eu-Tu caracteriza-se pela imediatez, pela reciprocidade e pela presença: 
A relação com o Tu é imediata. Entre o Eu e o Tu não se interpõe nenhum jogo de conceitos (keine Begriefflichkeit), nenhum esquema, nenhuma fantasia [...] Todo meio é obstáculo. Somente na medida em que todos os meios são abolidos, acontece o encontro (Begegnung).

[...] Somente na medida em que o TU se torna presente a presença se instaura. O EU da palavra-princípio EU-ISSO, o EU, portanto, com o qual nenhum TU está face-a-face presente em pessoa, mas que é cercado por uma multiplicidade de "conteúdos" tem só passado, e de forma alguma presente (BUBER, 2012, p. 57).

Nenhum intermediário se interpõe entre o Eu e seu interlocutor. "O essencial é vivido na presença, as objetividades no passado. [...] A relação imediata implica numa ação sobre o que se está face-a-face" (BUBER, 2012, p. 58). Essa imediatez está intimamente relacionada com a reciprocidade que caracteriza a relação, o encontro dialógico. Relação é reciprocidade. Meu TU atua sobre mim assim como EU atuo sobre ele (BUBER, 2012, p. 58).

Essa ontologia da relação, para Buber, é base de sua concepção do encontro do homem com o Absoluto, o Tu Eterno. "As linhas de todas as relações, se prolongadas, entrecruzam-se no Tu eterno" [...] Cada TU individualizado é uma perspectiva para ele. Através de cada TU individualizado a palavra-princípio invoca o TU eterno (BUBER, 2012, p. 99).

E acrescenta, mais adiante: "Em cada uma das esferas, graças a tudo aquilo que se nos torna presente, nós vislumbramos a orla do TU eterno, nós sentimos em cada TU um sopro provindo dele, nós o invocamos a maneira própria de cada esfera" (BUBER, 2012, p. 116).

Buber identifica o Tu eterno com Deus, ao afirmar:

Os homens têm invocado o seu TU eterno sob vários nomes. Quando cantavam aquele que era assim chamado, pensavam sempre no TU; os primeiros mitos foram cantos de louvor. Os nomes entraram, então, na linguagem do ISSO; um impulso cada vez mais poderoso levou os homens a pensarem no seu TU Eterno e falar dele como de um ISSO. Todos os nomes de Deus permanecem, no entanto, santificados, pois, não se fala somente sobre Deus, mas também se fala com Ele (BUBER, 2012, p. 99).

Outra característica apresentada por Buber é a exclusividade de toda relação imediata. "Toda relação atual com um ser presente no mundo 
é exclusiva. O seu TU é destacado, posto à parte, o único existente diante de nós" (BUBER, 2012, p. 101). A imediatez do encontro Eu-Tu está estreitamente vinculada ao caráter de exclusividade:

Na relação com Deus, a exclusividade absoluta e a inclusividade absoluta se identificam. Aquele que entra na relação absoluta não se preocupa com nada mais isolado, nem com coisas ou entes, nem com a terra ou com o céu, pois tudo está incluído na relação (BUBER, 2012, p. 101).

Como descrita na primeira parte do livro, o mundo da relação se realiza em três esferas, salienta Buber:

A primeira é a vida com a natureza. Nesta esfera a relação realiza-se numa penumbra como que aquém da linguagem [...]. A segunda é a vida com os homens. Nesta esfera a relação é manifesta e explícita: podemos endereçar e receber o TU. A terceira é a vida com os seres espirituais. Aí a relação, ainda que envolta em nuvens, se revela, silenciosa, mas gerando a linguagem. Nós proferimos, com todo nosso ser, a palavra-princípio sem que nossos lábios possam pronunciá-la (BUBER, 2012, p. 53).

E acrescenta: "Em cada uma das esferas, graças a tudo aquilo que se nos torna presente, nós vislumbramos a orla do TU eterno, nós sentimos em cada TU um sopro provindo dele, nós o invocamos a maneira própria de cada esfera" (BUBER, 2012, p. 53-54).

Em tal horizonte, Buber apresenta a noção de Revelação. Nesse encontro com o Tu eterno, o homem vivencia, não uma experiência interior (Erlebnis), nem tampouco um conhecimento comum. Trata-se de fé - emunah - e não gnose. O certo é que, nesse momento, o homem sofre uma ação. A Revelação é um ato de Deus.

Ainda outra coisa é certa: o homem recebeu algo que não possuía até então. O que ele recebe não é um "conteúdo", mas uma presença que é uma força transformadora do ser do homem. Essa presença, como força, não significa simplesmente que Deus está presente com uma presença ontológica, ou de imensidão, na linguagem teológica clássica. Há outra presença, própria ao espírito: é um impulso que desce sobre o ser, sem limite, como um movimento do Eu que tende, por sua ação, ao encontro supremo, à face a face com o Tu eterno. É preciso notar, também, que tal 
encontro revelador nada tem de uma maiêutica socrática; não se trata de uma lembrança, de uma reminiscência, de educação de alguma aptidão interior do homem. Deus se oferece, se abre ao homem; dá-lhe, no encontro pessoal, sua palavra: o Verbo, Davar.

Tal presença implica três fatos. O primeiro: “[...] toda plenitude da verdadeira mutualidade” (BUBER, 2012, p. 122). Em segundo lugar, “... é a inefável confirmação do sentido. Este sentido é garantido. Nada, nada mais pode ser sem sentido. A questão do sentido da vida não se coloca mais. Porém, se ela se colocasse, não precisaria ser respondida" (BUBER, 2012 p. 122). O problema do sentido da vida, se não é resolvido, pelo menos nada mais há a resolver: esse sentido não pede para ser interpretado ou compreendido, mas somente para ser realizado. Por quê? Porque esta é a terceira implicação, "[...] não se trata do significado de 'outra vida', mas de nossa vida, não de um 'além', mas deste nosso mundo, e ele quer que nós o coloquemos à prova, nesta vida, neste mundo" (BUBER, 2012, p. 122). Ele solicita que o realizemos e, quando o recebemos, não somos capazes de manifestá-lo e o desvendar. Não chegamos jamais a ter um conhecimento daquilo em face do que vivemos, daquilo de onde saímos ou daquilo onde entramos vivendo: é o mistério. Conforme Buber, a Revelação é um mistério da Presença. "Assim como nenhuma prescrição pode conduzir-nos ao encontro, do mesmo modo nenhuma nos faz dele sair" (BUBER, 2012, p. 123). Nós nos aproximamos de Deus; nós não avançamos no desvendamento do Ser. Esse evento é, essencialmente, uma prerrogativa de cada um, pois o que nos é revelado não o poderemos transmitir aos outros, como normas de conhecimento ou ação.

Aquilo diante do que vivemos, aquilo no que vivemos, a partir do qual e para o qual vivemos, o mistério, permaneceu como era antes. Ele se nos tornou presente e se nos revelou em sua presença como a salvação; nós o 'reconhecemos' sem, no entanto, termos dele um conhecimento que diminuísse ou atenuasse para nós o seu caráter misterioso. Nós nos aproximamos de Deus, mas não adiantamos na decifragem, no desvelamento do Ser. Sentimos a salvação, mas não a solução. O que recebemos não podemos levar aos outros dizendo: isto deve ser conhecido, isto deve ser feito. Só podemos ir e pôr à prova. E isso não é para nós uma simples obrigação, é um poder, um dever imperativo (BUBER, 2012, p. 123). 
Percebe-se, nessa obra, como Buber mostra seu entendimento da leitura da Bíblia hebraica. Afirma ele:

Tal é a revelação eterna, presente aqui e agora. Não conheço nenhuma revelação e não creio em nenhuma que não seja, em seu fenômeno originário, semelhante a esta. Eu não acredito em nenhuma autodenominação ou em uma auto-definição de Deus diante do homem. A palavra da revelação é esta: eu sou presente como aquele que sou presente (Ich bin da als der ich da bin). O que se revela é o que se revela. O ente está presente, nada mais. A eterna fonte de força brota, o eterno toque nos aguarda, a voz eterna ressoa (BUBER, 2012, p. 123) .

Buber não pretende discorrer sobre o que é Deus, não se pergunta sobre sua natureza essencial. Buber não é um metafísico e nem um teólogo. Ele não postula nenhuma tese metafísica e nem teológica. Como outros teólogos, ele não apresenta proposições teológicas sobre a natureza e atributos de Deus, nem sobre a salvação e outros conteúdos de fé.

Mas eu não sou absolutamente capaz nem mesmo disposto a ensinar isso ou aquilo sobre Deus. Certamente, quando eu procuro explicar o fato do homem, não posso desconsiderar que ele, o homem, vive diante de Deus. Não posso, porém, incluir o próprio Deus em qualquer ponto de minha explanação, do mesmo modo que não posso excluir da história a, para mim indubitável, obra de Deus nela, nem fazer dela objeto de minha contemplação (SCHILPP; FRIEDMAN, 1967, p. 690).

\section{Revelação e conhecimento}

Pode-se pensar Deus? Para Buber, não. Pode-se viver sua presença. O homem tenta construir uma história de Deus, a fim de compreender como se deu a transição, no âmbito de todas as religiões, para um Deuscoisa. É a presença cedendo o lugar para a forma. Nossa natureza tem uma tendência particular de querer sempre objetivar a Deus. Aqueles que

4 Para informação mais ampla, tomo a liberdade de remeter o leitor a textos de minha autoria: Martin Buber. Cumplicidade e diálogo (2003, p. 59-113); A questão do inter-humano: uma releitura de Eu e Tu de Martin Buber, 2008; Tu Eterno e religiosidade no pensamento de Martin Buber, 2015. 
afirmam a possibilidade do conhecimento de Deus, duma maneira objetiva, mesmo que concedam que Deus não se enquadre na categoria de objeto, se esforçam, contudo, por compreender o conhecimento de Deus, sob um modelo de conhecimento de objeto, numa relação Eu-Isso. A história das religiões nos mostra muitos exemplos de tentativas de objetivação de Deus, como objeto de fé, de culto. A questão aí não poderia ser, senão, de aproximações alegóricas. Uma relação autêntica com Deus não pode se produzir fora do encontro dialogal, baseado na palavra-princípio Eu-Tu.

Daí a afirmação de Buber, segundo a qual toda mística ou filosofia da identidade - partindo de pontos diferentes, mas com um mesmo fim, isto é, a procura de uma união com Deus, além do Eu-Tu - é ilusória. Todavia, como a força e a presença da Revelação se tornam "conteúdo"? Buber distingue nitidamente os termos "religiosidade", em oposição à "religião". O primeiro pertence ao domínio do Tu, na fé, ao passo que o segundo pertence ao mundo do Isso, dos ensinamentos doutrinais, dos conteúdos da fé, das instituições. Quando o homem sai da relação perfeita com o Tu eterno e retorna ao mundo do Isto, ele concebe Deus como uma coisa. Desse Deus ele pode falar; ele poderá questionar sobre sua essência, sobre sua ligação com os homens e com o mundo, tarefas que se propõem a filosofia e a teologia. As grandes religiões aludem a revelações, nas quais a própria divindade dá aos homens, de uma maneira ou de outra, o conteúdo de suas crenças; dessa forma, elas se baseiam em tais revelações. À luz de tais revelações, diversas doutrinas serão edificadas (diversas religiões), que serão objeto de fé para aqueles que acatarem tais religiões. O conteúdo dessas revelações consiste em ensinamentos sobre Deus, mas de sorte a ligá-lo, sobretudo, ao mundo do Isso, e não mostrando senão um Deus-coisa. Elas não permitem jamais ao homem encontrar o Tu eterno, o qual somente pode ser encontrado na relação Eu-Tu.

O Tu eterno não pode, por essência, tornar-se um Isso, pois não pode se deixar reduzir a uma medida ou a um limite, seja à medida da incomensurabilidade ou aos limites do ilimitado. Sua essência é de não poder ser concebido como uma soma de qualidades, nem mesmo como uma soma infinita de qualidades, e levadas à transcendência. Porque ele não se encontra nem no mundo, nem fora do mundo; porque ele não pode ser empiricamente conhecido; porque ele não pode ser pensado; porque pecamos 
contra Ele, que é o Ser, quando dizemos: Eu creio que ele existe; 'Ele' é ainda uma metáfora, mas 'Tu' não o 'é' (BUBER, 2012, p. 123).

Tudo o que podemos dizer de Deus e da religiosidade é ainda inadequado, equívoco. No "post-scriptum" à obra Eu e Tu, escrito em 1957, Buber salienta: "Sem dúvida, podemos somente falar sobre o que Deus é em sua relação com o homem” (BUBER, 2012, p. 136). Vemos que as revelações conhecidas não podem ser uma "presença" imediata do próprio Deus. É assim que a fé, para Buber, é compreendida como uma aceitação, um diálogo verdadeiro de Deus com o homem, uma interpelação de um Tu a um Eu, e uma resposta, no âmago da palavra realizada, do Verbo. A fé continua também intimamente ligada à Revelação (no sentido em que vimos), a qual vem de Deus para o crente.

A vida religiosa, nos seus momentos de experiência religiosa, se realiza numa troca incessante de atuação e latência das palavras-chave, das atitudes; momentos de encontro dialogal se sucedem à vida do Isso. A vida religiosa não é, pois, contínua, porém, antes, sujeita a um ritmo que nos coloca, sem cessar, em presença do mistério do encontro, mas nos fazendo, também, sem cessar, voltar para o mundo do Isso. É justamente essa descontinuidade que faz a dificuldade da vida religiosa, da experiência religiosa. No entanto, o homem tem uma sede ardente de continuidade, de uma extensão temporal. O ritmo de alternância entre atuação e latência da relação pura não o satisfaz. Aspira a possuir Deus, no tempo e no espaço. É assim que Deus será considerado como um objeto de fé. O que era, a princípio, um complemento do ato de relação perfeita, se torna, aos poucos, uma substituição pura e simples. Esse desejo ardente de continuidade ou possessão leva o homem a preferir, em vez do ritmo essencial continuamente renovado que vai do dobrar-se sobre si até a expansão, a escolher uma estagnação, uma estabilidade mais segura num Isso, no qual crê. O homem não se sente nem satisfeito nem seguro, na alternância à qual está sujeita a relação pura. E, contudo, por ocasião dessa relação perfeita com o Tu eterno, o que está latente, no estado de latência, não é a "presença original”, mas nosso próprio ser está presente, nossa força de relação. A própria estrutura da relação, do Eu na solidão, em face do Tu, que requer do homem que ele torne a se juntar ao mundo, não estanca essa sede de continuidade dentro dele. $\mathrm{O}$ que ele exige são manifestações, no espaço e no tempo, 
graças às quais uma comunidade pudesse se unir a Deus. É assim que Deus se torna um objeto de culto, um ser que se adora. Isso compromete, de certo modo, o caráter de reciprocidade do encontro e, por conseguinte, o significado da própria relação. Aqui observamos igualmente o mesmo fenômeno da substituição progressiva da relação pelo culto.

Na verdade, a relação pura não pode atingir a estabilidade espacio-temporal, senão na medida em que ela se encarna na substância inteira da vida. Ela não pode ser preservada, só pode ser posta à prova na ação, ela só pode ser realizada, efetivada na vida (BUBER, 2012, p. 125).

O homem só pode corresponder à relação com Deus, da qual ele foi "copartícipe", se ele realizar Deus no mundo. Aí se dá a autêntica continuidade, cuja garantia consiste no fato de que a relação pura, ao realizar-se, transforma os seres em Tu, elevando-os ao Tu Eterno, de modo que reverbere nele a palavra-princípio sagrada (Cf. BUBER, 2012, p. 125). A realização de Deus no mundo é a única garantia de continuidade. No fundo, a duração garantida significa somente a possibilidade de a relação pura se realizar plenamente, fazendo de todos os seres "Tu", de tal sorte que sejam ecos do Tu eterno. Buber emprega uma imagem para explicar essa garantia de estabilidade no espaço: consiste em raios que representam as relações dos homens, os quais se dirigem de todos os "Eus" pontuais para o centro, para o ser de verdade, o Tu, formando um círculo. São os raios, ou a relação comum com o centro, que têm a primazia sobre a periferia e a comunidade.

Se a Revelação é uma força, é igualmente uma vocação e uma missão. "O encontro com Deus não acontece ao homem para que ele se ocupe de Deus, mas que ele coloque à prova o sentido da ação no mundo. Toda Revelação é vocação e missão" (BUBER, 2012, p. 127). Na vocação, afirma Buber, Deus é presença. Em missão, ao percorrer "[...] o caminho, tem Deus diante de si; quanto mais fiel o cumprimento da missão, mais constante e intensa a proximidade. Ele não pode, sem dúvida, ocupar-se de Deus, mas pode entreter-se com ele" (BUBER, 2012, p. 127). A tendência de objetivar a Deus, no homem, faz que ele se volte, sem cessar, para o Revelador, ao invés de realizá-lo; o que o homem prefere é ter trabalho em Deus, e não com o mundo. Contudo, esse dobrar-se lhe oferece um Deus-coisificado, um Isso, e não o Tu de um encontro. Na vocação, Deus é 
sempre presença, ao passo que o dobrar-se sobre si faz de Deus um objeto. Os dois movimentos fundamentais do mundo, metacósmicos, segundo Buber, isto é, “[...] a expansão sobre o próprio ser, e a conversão para o estado de ligação", encontram sua forma humana mais alta, a verdadeira forma espiritual de seu conflito e de sua conciliação, de sua mistura e de sua separação, na história da relação do homem com Deus. Quando o homem sai enriquecido da relação com o Tu eterno, há também, no fundo, retorno (Umkher), pelo qual o homem abandona a solidão cristalizada do mundo coisificado, a fim de se dirigir ao verdadeiro mundo do encontro e da vida. Esse retorno procede, com efeito, de uma dupla operação: no início, da transformação do Eu, que lhe dá uma riqueza nova, e, em seguida no nascimento, sobre a terra, do próprio Verbo. Aqui também reconhecemos o aspecto rítmico. Após o retorno que produziu o nascimento do Verbo, a expansão vem fechá-lo na crisálida da religião e, em seguida, por uma nova conversão, o Verbo renasce outra vez. Se nós focalizarmos o aspecto ético da ontologia dialogal, veremos como o retorno é mais um ato que uma operação de passividade. A relação com o Tu eterno não é simplesmente uma operação realizada por um Eu, que endereça a palavra-chave da relação ao Tu absoluto; é igualmente uma decisão. E é essa categoria existencial que salvaguarda o aspecto dinâmico da relação, como um ato criador, e não como um estado sofrido. Essa decisão revela de alguma maneira a tarefa do homem: realizar Deus no mundo. Pela realização dessa presença, é revelada, também, a responsabilidade do homem na ordem ética. Pode ser que a religiosidade e o encontro com o Tu eterno nada mais sejam, afinal de contas, que outro nome da ética.

Para quem se apresenta diante da Face, o mundo só se torna realmente presente, à luz da eternidade, na plenitude da presença; ele pode então, de um só impulso, proferir o TU a todos, ao ser de todos os seres. Não há mais aí a tensão entre o mundo e Deus, mas somente a atualidade única. Tal homem não se libertou da responsabilidade, ele permutou a tormenta de uma responsabilidade finita, que procura resultados pelo poder do élan de uma responsabilidade infinita, a força de assumir com amor a responsabilidade por todos os acontecimentos inexploráveis do mundo o estar-inserido-no-mundo diante da Face de Deus (BUBER, 2012, p. 121). 
A tomada de consciência da responsabilidade e a identificação de Deus e do mundo são efetuadas de uma só feita. É, afinal, essa realização de Deus, essa identificação, que constitui a reviravolta do Eu, pela qual ele assume a responsabilidade para com o mundo. Assumir a responsabilidade da "cocriação" do mundo, e não dividir as duas dimensões de seu ser, a ética e a religiosa, em outras palavras, não separar o estágio da ação e o estágio da contemplação, isso é que constitui a essência da relação perfeita, o face a face com o Tu eterno.

Contudo, existe uma diferença qualitativa na relação, nas diversas épocas históricas. A certa época, o espírito humano foi suprimido, enterrado, em certo sentido; em outra época, morre e se prepara para a relação. O elemento se transforma, por conseguinte, ao longo da história, e novos domínios do mundo e do espírito são, sem cessar, elevados à forma divina.

Nas formas criadas, essas esferas novas, tornadas lugar da teofania, não são nem o poder do homem, nem a presença de Deus, que agem, mas sim uma mistura de divino e humano. Nesse sentido, pondera Buber:

É assim, pois que ao longo do caminho da História, através das transformações do elemento humano, são chamados à forma divina sempre novos domínios do mundo e do espírito. Esferas sempre novas tornam-se o lugar da teofania. O que aqui atua não é mais o poder próprio do homem, também não é a pura passagem de Deus, é uma mistura de divino e humano (BUBER, 2012, p. 127).

Se a forma é uma mistura do Tu e do Isso, contudo, Deus permanece próximo a ela por tanto tempo quanto o culto e a fé estão unidos pela verdadeira oração, para tornar-se relação perfeita. Se a oração se degenera, o homem sente que o poder de seu ser inteiro e indiviso de dizer Tu se torna, aos poucos, mais fraco. Para dizer realmente Tu, o homem sai da falsa segurança da comunidade, de modo a entrar na última solidão da aventura do infinito.

Mas o caminho não é circular. Ela é o caminho. Em cada novo Éon, a fatalidade se torna mais opressora, o retorno (Umkher) mais desorganizador. E a teofania se torna cada vez mais próxima; ela se aproxima sempre mais da esfera do "entre" os seres; aproxima-se do reino que se esconde no meio de 
nós, no Entre-nós. A história é uma misteriosa reaproximação. Cada uma das espirais do caminho nos conduz, ao mesmo tempo, para uma perdição mais grave, e para um retorno mais fundamental. Mas, o evento que, visto da parte do mundo, é um retorno, visto da parte de Deus se chama Redenção (BUBER, 2012, p. 128).

\section{Considerações finais}

Judeus e cristãos compartilham a crença de que Deus entra em contato com o mundo e com os homens. Vimos a crítica lançada pelo pensamento moderno contra a ideia de Revelação, baseada no argumento de que esta seria incompatível com o seu princípio fundamental, que é a investigação racional. A partir do momento em que Kant postulou a diferença entre númeno (noumenon) e fenômeno (phainomenon), tornou-se possível argumentar que a realidade pode deixar de ser um objeto, na medida em que não a vermos como objeto, necessariamente desvinculada do sujeito. Pode-se, entretanto, manter uma relação de compromisso. Esse compromisso permite sustentar um acesso cognitivo do transfenomenal. A busca, por meio de conhecimentos ou pela relação de causalidade, cede o lugar ao encontro imediato e direto. Assim, podemos compreender as ponderações de Buber sobre a Revelação. Ela é o evento que entra nessa dimensão da realidade transfenomenal. Revelação, para Buber, mais do que um conjunto de informações sobre sua essência e seus atributos, é um encontro do homem com a Presença do Tu Absoluto. A Revelação não é um texto escrito, mas uma Voz proferida no momento presente, numa situação presente em toda sua concretude. Moisés, ao indagar a Javé pelo seu nome, ouviu a voz: "Eu sou presente como aquele que sou presente".

As considerações em Eu e Tu não formam um corpo de proposições metafísicas ou epistemológicas, nem tão pouco podem ser entendidas como reflexões meramente místicas ou, muito menos uma longa homilia, propondo-se como guia espiritual. A noção de Revelação, de acordo com Buber, está intimamente imersa no horizonte de significado de Eue Tu, cuja charneira é a dupla de "palavras-princípio", eixo seminal na compreensão da existência humana em suas relações como o mundo, com outros homens e com Deus. Penso mesmo que se pode conceber essa obra, atribuindo-lhe a mesma expressão com que Buber se definiu: eu sou um homem atípico. 
Na verdade, Eu e Tu é uma construção atípica. Esse livro será considerado posteriormente como a obra de arte da literatura alemã. Qualificado como elegante, de imensa beleza e intensa exaltação espiritual, esse texto seria objeto de discussões apaixonadas a respeito de sua visão do religioso, da experiência extática e da mística. Não é pretensão minha apresentar as diversas análises críticas endereçadas por eminentes autores de diferentes áreas. No entanto, são pertinentes algumas considerações sobre determinadas características desse singular pensador. Noto, de início, sua posição em relação à linguagem. O encontro do homem com outro homem e do homem com Deus são duas vertentes da experiência existencial da linguagem, o caminho da comunicação entre humanos e do homem com o Tu eterno. A relação inter-humana simboliza a relação com Deus, na qual a invocação receba a resposta. É de se observar que, para o nosso autor, tal relação entre o homem e o Tu eterno se distancia das instituições da fé estabelecida, dos dogmas e ritos, das fórmulas e autoridades sempre contestadas por Buber. A relação da Revelação é um diálogo interpessoal, face-a-face. Buber está vinculado à tradição bíblica, a uma tradição da palavra.

Observe-se, ademais que o ponto específico da originalidade da intuição buberiana reside não meramente no postulado segundo o qual o homem é um ser de relação. Muitos outros pensadores e filósofos já argumentaram em prol dessa tese. Sua especificidade se funda na concepção do estatuto epistemológico do "conhecimento" Eu-Tu e do conhecimento coisificante Eu-Isso, de um lado, e, de outro, do estatuto metafísico do Tu e do Isso. Na verdade, Buber sustenta que, na relação Eu-Tu engajada, há um acesso de conhecimento do outro que é inacessível de outro modo a não ser por esse. Destaca Buber: "A palavra-princípio EU-TU só pode ser proferida pelo ser na sua totalidade" (BUBER, 2012, p. 51). Ademais, a relação Eu-Isso é um conhecimento desengajado, que visa a um Isso, conhecimento inferior, uma distância que se estabelece entre o Eu e o outro, a qual se torna um Isso. Equivocam-se aqueles que, interpretando essa questão de Buber, reduzem, no plano epistemológico, a natureza do conhecimento presente na relação Eu-Tu a um conhecimento do tipo Eu-Isso. Buber é enfático ao afirmar que a Revelação não pode ser considerada a não ser no âmbito ontológico existencial do Eu-Tu. Nesse sentido, há um tipo específico de conhecimento nessa relação recíproca: 
a palavra é endereçada como apelo e a resposta é dada; há comunicação e não somente utilização e observação e ação sobre um objeto. O que Deus "fala" em cada situação do encontro Eu-Tu transcende qualquer antecipação conceitual. A Revelação manifesta o Tu absoluto, o eterno "presente" (eyheh). A resposta à interpelação na relação com o Tu eterno envolve um engajamento do homem em "voltar-se para", a fim de completar a relação dialógica. "As palavras-princípio não exprimem algo que pudesse existir fora delas, mas uma vez proferidas elas fundamentam uma existência" (BUBER, 2012, p. 51).

Deve-se observar que Buber não exclui o entendimento da Revelação considerada, no sentido clássico, como a comunicação de uma verdade por um autor inspirado por Deus, cuja mensagem foi confirmada por sinais. Do mesmo modo, é equivocada a afirmação segundo a qual Buber desqualifica o mundo do Isso.

Cada TU, após o término do evento da relação deve necessariamente se transformar em ISSO. Cada ISSO pode, se entrar no evento da relação, tornar-se um TU. Estes são os dois privilégios fundamentais do mundo do ISSO. Eles impelem o homem a considerar o mundo do ISSO como o mundo no qual se deve viver, no qual se pode viver, o mundo que oferece toda espécie de atrações e estímulos de atividades e conhecimentos. [...] E com toda a seriedade da verdade, ouça: o homem não pode viver sem o ISSO, mas aquele que vive somente com o ISSO não é homem (BUBER, 2012, p. 71-72).

A Revelação é, na verdade, um ato de Deus. Afirma Buber:

As revelações poderosas que estão na origem das grandes comunidades, nos movimentos de transição das etapas da humanidade, nada mais são do que eterna revelação. A revelação, no entanto, não é derramada sobre o mundo através de seu destinatário, como se o fosse através de um funil; ela chega a ele, ela o toma em sua totalidade, em todo o seu modo de ser e se amalgama a ele. Também o homem, que é a "boca", é exatamente a boca e não um porta-voz, não é um instrumento, mas um órgão que soa segundo suas próprias leis, e soar é transformar (BUBER, 2012, p. 126-127). 
Note-se que Buber usa de um jogo de palavras com os verbos do idioma alemão lauten - soar, e umlauten cujo significado é inflectir, modificar a voz, a entonação. Assim, entendo que sua intenção foi identificar, no contexto, soar com modificar, transformar.

É de se notar o estreito vínculo de fertilização mútua entre o pensamento e a vivência concreta desse pensador. Sua obra busca na fonte de seu existir histórico as inspirações seminais para as suas reflexões, nos mais diversos domínios, numa hierarquia a partir da fonte principal, que é o judaísmo. E suas reflexões vão orientando suas ações de modo singular, nos vários momentos de sua vida.

É razoável entender que essa reflexão "religiosa” de Buber, em Eu $e \mathrm{Tu}$, abre caminho para uma ética, pois essa sabedoria que ultrapassa o elemento puramente objetivo das religiões para chegar à "religiosidade" concreta propõe uma dupla tarefa ao homem: em primeiro lugar, a realização do divino, de tal sorte que uma teofania seja desdobrada em verdadeira história; em segundo lugar, a construção de um cosmos que seja a moradia do homem. O divino seria como uma espécie de leitura absoluta do humano, pois, na realidade, esse humano é o objetivo que tal mensagem almeja realizar plenamente. Ademais, não é só na dimensão ética que o homem tem o encargo do divino; é também numa dimensão ontológica, podemos asseverar. Onde poderíamos encontrar, com efeito, um significado concreto e uma explicação antropológico-filosófica sobre o conceito do encontro perfeito, do face a face com o Tu eterno, senão no próprio homem? Sem a referência essencial à experiência humana do encontro dialógico Eu-Tu com outrem, tal doutrina não teria sentido. Sem dúvida, em sua obra principal, Buber seguiu uma via que começa pelo estudo da relação com outrem, ou com um Tu individualizado, em suma, o mundo do homem, para depois chegar, por aperfeiçoamento, ao estudo da relação com o Tu eterno. Podemos ver nessa diligência o elemento humano que serve de alguma maneira como preparação, como antessala, antes de entrar no "santuário" da relação perfeita.

Merece destaque, igualmente, observar o fato de Buber atribuir a Deus o caráter de Tu eterno, de Pessoa Absoluta, ou de um ser que se torna pessoa, a fim de conhecer e ser conhecido, amar e ser amado. É um ponto delicado, porque essa atribuição do caráter pessoal poderia parecer uma limitação a 
Deus, se, como o místico, se pudesse entender por personalidade uma limitação. Buber é muito claro ao afirmar que nós não podemos conhecer a Deus em seu próprio ser. Ele é acessível à nossa compreensão, ao nosso conhecimento, somente enquanto pessoa, pois é como pessoa que Ele nos encontra e que podemos encontrá-lo na relação. É o tipo de "conhecimento" a que se aludiu cima, um conhecimento Eu-Tu. É preciso perceber, contudo, que os Tu individualizados, as pessoas com as quais nos encontramos, são limitados, ao passo que Deus não tem limites. Buber o chama então de Pessoa Absoluta. Dir-se-á que há uma contradição, quando nos referimos ao conteúdo da noção de pessoa. Essa noção implica uma relatividade - embora sua individualidade exista em si - com relação às outras individualidades, no seio do Ser. Isso é verdade; todavia, não pode acontecer com Deus. Buber opõe a esse argumento a designação paradoxal, sem dúvida, de Deus como uma Pessoa Absoluta, isto é, como uma pessoa que não pode ser relativa. O próprio autor apresenta a questão, ao enfatizar, no mesmo post-scriptum:

A relação com Deus como pessoa é indispensável para quem, como eu, não entende por "Deus" um principio, embora místicos como mestre Eckart, às vezes $\mathrm{O}$ assemelham ao Ser; para aquele que, como eu, não identifica "Deus" com uma idéia, embora filósofos como Platão, possam, às vezes, tê-lo concebido como tal; para quem, sobretudo, como eu, entende por "Deus" - não importa o que seja, além disso - aquele que entra numa relação imediata conosco homens, através de atos criadores, reveladores e libertadores possibilitando-nos, com isso, a entrar em uma relação imediata com Ele (BUBER, 2012, p. 137).

E mais adiante, acrescenta:

Porém, agora no que diz respeito ao conteúdo universalmente conhecido do conceito de Pessoa, se anuncia a contradição. Não pertence à essência da pessoa o fato de sua individualidade, embora existindo em si, ser relativizada na totalidade do Ser pela pluralidade de outras individualidades? Mas, evidentemente, isso não se aplicaria a Deus. A esta contradição contrapõe-se a designação paradoxal de Deus como pessoa absoluta, isto é, uma pessoa não passível de relativização. Deus entra na relação imediata conosco como pessoa absoluta. A contradição desaparece em um nível superior de consideração (BUBER, 2012, p. 137). 
Em outras palavras, Deus confere tal caráter de absoluto à relação na qual ele entra. Isso significa, então, que Deus é pessoa? O caráter absoluto de sua personalidade, o paradoxo dos paradoxos, proíbe tal afirmação. Isso significa que Deus ama como uma pessoa, e quer ser amado como uma pessoa. Realmente, o conceito da qualidade de pessoa é incapaz de definir a essência de Deus; mas nada impede de dizer que Deus seja também uma pessoa. E Buber afirma, em um ensaio: "O amor de Deus e a ideia de Deus" , que, se não fosse uma pessoa, Deus se tornaria pessoa, por assim dizer, ao criar o homem, a fim de amá-lo e de ser amado por ele. Nós amamos o próprio Deus, e não a ideia de Deus. E mesmo que as ideias pudessem ser amadas, não haveria senão pessoas capazes de amar. Em outras palavras, é permitido ao fiel crer que Deus se torna uma pessoa por seu amor, pois, em nosso modo humano de existir, a única relação recíproca é a relação pessoal (BUBER, 2007). É legítimo, portanto, falar-se da pessoa de Deus, na relação religiosa e em sua linguagem, porém, ao fazê-lo, não estamos fazendo uma afirmação sobre o Absoluto, o que o reduziria ao pessoal.

Conforme Friedman, o Tu eterno não seria um símbolo do próprio Deus, mas, antes, de nossa relação com Ele (FRIEDMAN, 1955, p. 225). E Buber acrescenta, em Eu e Tu:

Deus — podemos agora afirmar — transmite sua absoluticidade à relação que Ele estabelece com o homem. O homem que se dirige a Ele não tem necessidade de se afastar de nenhuma outra relação EU-TU; ele as conduz legitimamente a Ele e as deixa que se transfigurem na "face de Deus" (BUBER, 2012, p. 137-138).

Pode-se afirmar, penso eu, que Buber emprega o termo Tu eterno por duas razões: a primeira, para marcar bem a simplicidade e a intimidade quase familiar dessa relação, a qual deve se inserir em nossa vida de cada dia; em segundo lugar, para significar que, nesse encontro, por mais perfeito que seja, não podemos objetivar a Deus, se Ele, realmente, estiver em relação dialogal conosco.

5 Esse ensaio compõe a obra Eclipse de Deus. Encontra-se, na tradução brasileira, nas páginas 47 a 59. 
Buber conclui, reiterando literalmente a íntima relação entre o plano transfenomenal do Eu em relação ao Tu Absoluto, de um lado, e a vida cotidiana numa autêntica experiência religiosa, de outro. Assim, ressalta ele:

A palavra pessoal torna capaz e exige, evento após evento, situação após situação, da pessoa humana firmeza e decisão. Acreditamos muitas vezes, que nada há a perceber, mas obstruímos há muito tempo, nossos ouvidos. A existência da mutualidade entre Deus e o homem é indemonstrável, do mesmo modo que a existência de Deus é indemonstrável. Porém, aquele que tenta falar dEle dá seu testemunho e invoca o testemunho daquele a quem Ele fala, seja um testemunho presente ou futuro (BUBER, 2012, p. 138).

Note-se, finalmente, a preocupação sempre presente nessas reflexões, vale dizer, reafirmar a urgência em se promover o "diálogo entre o céu e a terra”, o encontro entre o homem e Deus. E, na Revelação,

[...] o homem recebe e o que ele recebe não é um "conteúdo", mas uma presença, uma presença que é uma força [...]. O que tem ele a ver conosco então? O que exige de nós este sentido revelado, mas oculto? Ele não é interpretado - isso não nos é possível - ele só quer que o realizemos (BUBER, 2012, p. 122).

Buber defende a prioridade do sentido da existência humana no encontro com o Tu divino. Em acréscimo, que ele não se resume a uma construção sistemática de pensamentos.

Se pensarmos na crítica moderna, a qual a ideia mesma de Revelação, é pertinente entender a noção que Buber apresentou de Revelação como uma resposta a essa crítica, ao distinguir claramente os dois significados de conhecimento, como foi visto. E, de fato, interpretar a obra Eu e Tu e o teor das intuições e considerações ali expostas, meramente como obra de um filósofo, de um teólogo ou de um cientista da religião, não tem fundamento sólido. Ele pôde ser tudo isso, no entanto, creio plausível considerar Martin Buber um sábio hebreu em trajes modernos, um profeta do secularismo religioso. Ele é um sábio, pois a base mesma de sua mensagem é um compromisso não argumentável com o diálogo do Deus de Israel, ao qual os homens estão convidados a aderir "com todo o seu ser". 


\section{Referências}

BUBER, M. Judaïsme. Lagrasse (France): Verdier, 1982.

BUBER, M. Eclipse de Deus. Trad. Carlos Almeida Pereira. Campinas: Verus, 2007. (Gottesfinsternis. Zürich: Manesse, 1953).

BUBER, M. Eu e Tu. Trad. Newton Aquiles von Zuben. 10. ed. São Paulo: Centauro, 2012. (1ª edição brasileira, 1979. Ich und Du. 6. ed. Heidelberg: Lambert Schneider, 1974).

FRIEDMAN, M. The life of dialogue. Londres: Routledge and Kegan Paul, 1955.

HORWITZ, R. Buber's way to "I and Thou". An Historical Analysis and the first publication of Martin's Buber Lectures "Religion als Gegenwart". Heidelberg: Lambert Schneider, 1978.

SCHILPP, P. A.; FRIEDMAN, M. The philosophy of Martin Buber. London: Cambridge University Press, 1967.

Recebido: 03/02/2016

Reçu: 03/02/2016

Aprovado: 08/06/2017

Approuvé: 08/06/2017 